\title{
Biodegradation Potentials of Waste Engine Oil by Three Bacterial Isolates
}

\author{
1"ENERIJIOFI, KE; ${ }^{2}$ AHONSI, CO; ${ }^{*}$ AJAO, EK \\ ${ }^{* 1}$ Department of Biological Sciences, College of Basic and Applied Sciences, \\ Samuel Adegboyega University, Km 1, Ogwa - Ehor Road, P. M. B. 001, Ogwa, Edo State, Nigeria \\ ${ }^{2}$ Nigeria Natural Medicine and Development Agency, Lagos, Ngeria \\ "Corresponding Author Email: kingsmore1luv@gmail.com; kenerijiofi@sau.edu.ng; Tel: 08034553580
}

\begin{abstract}
Environmental contamination by waste engine oil in cities all over the world constitute serious public health concern because its effects are unwholesome and unquantifiable. This study was carried out to biodegrade waste engine oil using bacterial isolates. Three bacteria were isolated from soil samples that have been contaminated with waste engine oil for over seven years in automechanic workshops at Ebelle. They were analysed using standard methods. The bacterial count was $89.4 \pm 0.02 \mathrm{cfu} / \mathrm{g}$ while the control was $3.6 \pm 0.14 \mathrm{cfu} / \mathrm{g}$. The bacterial diversity identified in descending order were Bacillus sp. (25.41\%), Pseudomonas sp. (22.13\%), Corynebacterium sp. (18.44\%), Acetobacter sp. (18.03\%) and Aeromonas sp. (15.98\%). The biodegradation efficiencies of three bacterial isolates; Bacillus, Pseudomonas and Corynebacterium species were observed taking records of change in physicochemical parameters $(\mathrm{pH}$, electrical conductivity and total hydrocarbon content) for 40 days at 10 days interval with waste engine oil sample at concentrations of $10 \%, 20 \%, 30 \%$ and $40 \%$. Corynebacterium sp. gave the highest percentage reduction in $\mathrm{pH}$ values of $52.92 \%$ at $10 \%$ contamination level while Pseudomonas sp. gave the highest percentage reduction of $53.04 \%, 52.99 \%$ and $53.01 \%$ at $20 \%, 30 \%$ and $40 \%$ crude oil contamination levels respectively. The $\mathrm{pH}$ values of the control was almost the same all through the period of incubation. Bacillus sp. gave the highest percentage increase in electrical conductivity value of $74.17 \%, 69.93 \%$ and $69.91 \%$ at $10 \%, 20 \%$ and $40 \%$ contamination level respectively while Pseudomonas sp. gave the highest increase of $70.45 \%$ at $30 \%$ contamination level. Also, the values at day 0 and the control were not so different from each other. Corynebacterium sp. gave the highest percentage reduction in total hydrocarbon content of $95.49 \%, 95.48 \%, 96.50 \%$ and $96.50 \%$ at $10 \%, 20 \%, 30 \%$ and $40 \%$ contamination level respectively. The result revealed a reduction in $\mathrm{pH}$ and total hydrocarbon content while there was an increase in electrical conductivity values. This indicated that biodegradation occurred. This study revealed that the bacterial isolates particularly Corynebacterium sp. possess the ability to biodegrade waste engine oil thereby guaranteeing environmental quality and sustained public health for all and sundry.
\end{abstract}

\section{DOI: https://dx.doi.org/10.4314/jasem.v24i3.14}

Copyright: Copyright (C) 2020 Enerijiofi et al. This is an open access article distributed under the Creative Commons Attribution License (CCL), which permits unrestricted use, distribution, and reproduction in any medium, provided the original work is properly cited.

Dates: Received: 16 November 2019; Revised: 11 January 2020; Accepted: 22 February 2020

Keywords: biodegradation, Corynebacterium sp., environmental sustainability, total hydrocarbon content

Engine oil constitute one of the numerous products from crude oil refining and it consist of long-chains saturated hydrocarbons which is utilised in lubricating automobile engines parts so as to keep them at optimal use at all time (Meeboon et al., 2016). The greatest characteristic feature of lubricating oil is in reducing the viscosity of automobiles, though it is usually made up of about two percent of crude oil, it is the most commonly utilised of all petroleum fractions (Obayori et al., 2015). Used engine oil is one of the sources of soil pollution with hydrocarbons as it contains petroleum ether, naphthalene, mineral spirits, benzene, kerosene, paraffin wax, fuel oil, gasoline, lubricating oil and asphalt. However, used car oil has much higher concentrations of polycyclic aromatic hydrocarbons compared with new motor oil (Bharathi et al., 2017).

A lot of microbes that are extensively ubiquitous in nature possess the capability to make use of hydrocarbons as lone source of carbon and energy for their metabolic activities (Ajuzie et al., 2015). However, the ability of microorganisms to utilize hydrocarbons is dependent on some factors like the chemical nature of the compounds in the crude oil mixture as well as some environmental conditions (Adeline et al., 2009; Wang et al., 2013). Indeed, in biodegradation process, organic compounds are reduced to its constituents by microorganisms and when it is complete, it is called "mineralization" (Marinescu et al., 2009; Enerijiofi and Chukwuma, 2018). Microbes are able to change the constituents through enzymatic or metabolic processes via the utilization as either growth or co-metabolic substrate (Ajuzie et al., 2015). Bioremediation is divided into three distinct stages; natural attenuation, in this the pollutants are degraded by indigenous microbes in the absence of human interference; biostimulation where there are improvement in the oxygen and nutrients levels that are applied to the systems thereby enhancing their capabilities to speed up the entire process and bioaugmentation, a process whereby potent microbial 
degraders are added to the system so as to enhance the degradation of the target contaminant (Azubuike et al., 2016).

The improvement in technology has led to the manufacture of a variety of automotives which have led to a corresponding increase in the utilization of lubricating oil. Also, oil spills from filling stations, loading and pumping stations, petroleum depots, workshops of auto mechanics as well as during transportation are contributing substantially to the contamination in soil (Chen et al., 2013). This has attracted the attention of the public since most of the polyaromatic hydrocarbons are carcinogenic and mutagenic to humans, animals and toxigenic to vegetations (Balachandran et al., 2012). The challenges associated with pollution have led to the search for numerous corrective methods to effectively remediate the contaminated soils. The use of physicochemical method as a clean - up strategy has intensified the issue instead of eradicating it while mechanical methods are expensive and time consuming (Pandey et al., 2016). However, the use of living organisms is considered a good alternative for remediating contaminated sites principally resulting from the use of relatively cheap equipment, friendliness to the environment as well as its simplicity. Though environmental factors as well as nutrients availability have profound influence on microorganisms, they also determine the degree and scope of degradation. This study was carried out to biodegrade waste engine oil samples using three bacterial isolates.

\section{MATERIALS AND METHODS}

Sources of Polluted Soil Samples and Pollutant: Waste engine oil polluted soil were collected from auto mechanic workshops located at Ebelle in Igueben Local Government Area, Edo State. Sterile polythene bags were used to collect the contaminated soil samples and taken to the laboratory for bacterial isolation and degradation studies. The waste engine oil used for biodegradation studies was obtained from petrol filling station in Benin City, Edo state.

Enumeration, Isolation and Identification of Bacterial Isolates from Polluted Soil Samples: One (1) gram of composite contaminated soil sample was weighed into a sterile beaker and $9 \mathrm{ml}$ of sterile distilled water was added to make up the stock. This was serially diluted using ten-fold serial dilution, up to $10^{-10}$. Aliquot $1 \mathrm{ml}$ of dilutions $\left(10^{-3}, 10^{-6}\right.$ and $\left.10^{-9}\right)$ were plated on nutrient agar for bacterial isolation. The cultures were incubated at $37^{\circ} \mathrm{C}$ for 24 hours. Thereafter, a sterile wire loop was used to pick a single distinct colony of each bacterium and sub-cultured on fresh nutrient agar medium. The cultures were incubated at $37^{\circ} \mathrm{C}$ for 24 hours. Pure cultures of the various distinct isolates were made and stored in the refrigerator. The distinct colonies were subjected to cultural, morphological, biochemical and sugar fermentation tests. The results were confirmed with Bergey's manual of determinative bacteriology (Enerijiofi and Chukwuma, 2018).

Determination of Bioremediation Activities of the Bacterial isolates: The waste engine oil was used as sole carbon source in mineral salt medium (MSM) broth for the bioremediation experiment. Sterile conical flask containing $500 \mathrm{ml}$ of MSM broth and $10 \mathrm{mls}$ of sterile waste engine oil of varying concentrations $(10,20,30$ and $40 \%$ contamination levels) were prepared. Each flask was covered with cotton wool, wrapped with aluminium foil and autoclaved at $121^{\circ} \mathrm{C}$ for $15 \mathrm{~min}$. A sterile inoculating loop was used to pick inoculum from the pure culture, each of Pseudomonas, Corynebacterium and Bacillus isolate and transferred into sterile labelled flasks. The cultures were incubated at $30^{\circ} \mathrm{C}$ in an incubator over a period of 40 days. Each flask was agitated twice daily to enhance homogenization and aeration throughout the experiment. During the incubation period, $10 \mathrm{ml}$ from each culture was collected at 10 days interval to determine the biodegradation parameters which were $\mathrm{pH}$, electrical conductivity (EC) and total hydrocarbon content (Shittu and Ogor, 2018).

Statistical Analysis: Each treatment was in three replicates and results were presented as mean \pm standard error.

\section{RESULTS AND DISCUSSION}

The total heterotrophic bacterial count is recorded in Table 1. The contaminated soil recorded $89.4 \pm 0.02 \mathrm{x}$ $10^{6} \mathrm{cfu} / \mathrm{g}$ which was far higher than the Control, $3.6 \pm$ $0.14 \times 10^{6} \mathrm{cfu} / \mathrm{g}$. Table 2 recorded the percentage prevalence of the bacterial isolates in waste engine oil contaminated soil samples at $20 \%, 30 \%$ and $40 \%$ between $53.01 \%$ and crude oil. Bacillus sp. (25.41\%) was the most prevalent isolate followed by Pseudomonas sp. (22.13\%) and Corynebacterium sp. $(18.44 \%)$. The different $\mathrm{pH}$ values at varying concentrations of waste engine oil with bacterial inoculum in the mineral salt medium are recorded in Table 3. From the three bacterial isolates studied, the result revealed that Corynebacterium sp. gave the highest percentage reduction in $\mathrm{pH}$ values of $52.92 \%$ at $10 \%$ contamination level while Pseudomonas sp. gave a reduction of $53.04 \%, 52.99 \%$ and $53.01 \%$ crude oil contamination level respectively. The $\mathrm{pH}$ values of the control experiment (uninoculated MSM broth, amended with waste engine oil) remained almost the same throughout the incubation period. 
Table 1: Results for Enumeration of Bacterial Count X $10^{6} \mathrm{cfu} / \mathrm{g}$

\begin{tabular}{lll}
\hline Bacterial Count & Mean & Control \\
\hline THBC & $89.4 \pm 0.02$ & $3.6 \pm 0.14$ \\
\hline
\end{tabular}

Legend: THBC - Total Heterotrophic Bacterial Count;

Values represent mean \pm standard error of triplicate samples

Table 2: Percentage prevalence of Bacterial isolates from waste engine oil contaminated soils

\begin{tabular}{ll}
\hline Bacterial isolate & Percentage prevalence n (\%) \\
\hline Pseudomonas $\mathrm{sp}$. & $54(22.13)$ \\
Corynebacterium $\mathrm{sp}$. & $45(18.44)$ \\
Bacillus $\mathrm{sp}$. & $62(25.41)$ \\
Aeromonas $\mathrm{sp}$. & $39(15.98)$ \\
Acetobacter $\mathrm{sp}$. & $44(18.03)$ \\
Total & $\mathbf{2 4 4}$ \\
\hline
\end{tabular}

Table 4 shows the detailed Electrical conductivity values at varying concentrations of waste engine oil with bacterial inoculum in the mineral salt medium. From the three bacterial isolates examined, the result revealed that Bacillus sp. gave the highest percentage increase in electrical conductivity value of $74.17 \%$, $69.93 \%$ and $69.91 \%$ at $10 \%, 20 \%$ and $40 \%$ contamination level respectively while Pseudomonas sp. gave the highest of $70.45 \%$ at $30 \%$ contamination level. Also, the values at day 0 were not so different from each other. Table 5 recorded the total hydrocarbon content values at varying concentrations of waste engine oil with bacterial inoculum in the mineral salt medium. It was observed that Corynebacterium sp. gave the highest percentage reduction of $95.49 \%, 95.48 \%, 96.50 \%$ and $96.50 \%$ at $10 \%, 20 \%, 30 \%$ and $40 \%$ contamination level.

Table 3: $\mathrm{pH}$ values of MSM amended with varying concentrations of waste engine oil Inoculated with selected bacterial isolates

\begin{tabular}{llllllll}
\hline Bacterial isolates & $\begin{array}{l}\text { WEO } \\
\text { Conc. }\end{array}$ & Day 0 & Day 10 & Day 20 & Day 30 & Day 40 & $\begin{array}{l}\text { Percentage } \\
\text { Reduction }\end{array}$ \\
\hline Pseudomonas sp. & $10 \%$ & $6.55 \pm 0.03$ & $4.76 \pm 0.02$ & $4.67 \pm 0.01$ & $3.71 \pm 0.12$ & $3.09 \pm 0.22$ & 52.82 \\
& $20 \%$ & $6.54 \pm 0.01$ & $4.74 \pm 0.01$ & $4.56 \pm 0.11$ & $3.60 \pm 0.20$ & $3.07 \pm 0.13$ & 53.01 \\
& $30 \%$ & $6.51 \pm 0.01$ & $4.71 \pm 0.11$ & $4.34 \pm 0.21$ & $3.54 \pm 0.04$ & $3.06 \pm 0.05$ & 52.99 \\
Corynebacterium sp. & $40 \%$ & $6.41 \pm 0.02$ & $5.72 \pm 0.12$ & $4.52 \pm 0.17$ & $3.42 \pm 0.08$ & $3.06 \pm 0.31$ & 53.01 \\
& $10 \%$ & $6.50 \pm 0.01$ & $4.65 \pm 0.15$ & $4.59 \pm 0.21$ & $3.77 \pm 0.23$ & $3.01 \pm 0.02$ & 52.92 \\
& $20 \%$ & $6.41 \pm 0.21$ & $4.60 \pm 0.31$ & $4.48 \pm 0.25$ & $3.68 \pm 0.13$ & $3.04 \pm 0.14$ & 52.57 \\
Bacillus sp. & $30 \%$ & $6.37 \pm 0.12$ & $4.51 \pm 0.25$ & $4.44 \pm 0.14$ & $3.54 \pm 0.21$ & $3.02 \pm 0.10$ & 52.59 \\
& $40 \%$ & $6.22 \pm 0.14$ & $4.37 \pm 0.18$ & $4.39 \pm 0.20$ & $3.36 \pm 0.14$ & $3.01 \pm 0.21$ & 51.61 \\
& $10 \%$ & $6.48 \pm 0.30$ & $5.02 \pm 0.20$ & $4.48 \pm 0.13$ & $3.56 \pm 0.24$ & $3.08 \pm 0.15$ & 52.50 \\
Control & $20 \%$ & $6.43 \pm 0.22$ & $5.00 \pm 0.16$ & $4.44 \pm 0.12$ & $3.49 \pm 0.11$ & $3.06 \pm 0.11$ & 52.41 \\
& $30 \%$ & $6.38 \pm 0.03$ & $94 \pm 0.15$ & $4.40 \pm 0.12$ & $3.37 \pm 0.21$ & $3.04 \pm 0.01$ & 52.35 \\
& $40 \%$ & $6.32 \pm 0.19$ & $4.36 \pm 0.11$ & $4.37 \pm 0.29$ & $3.21 \pm 0.12$ & $3.02 \pm 0.10$ & 52.22 \\
& $10 \%$ & $6.85 \pm 0.01$ & $6.55 \pm 0.01$ & $6.35 \pm 0.20$ & $6.01 \pm 0.12$ & $5.34 \pm 0.10$ & 22.04 \\
& $20 \%$ & $6.81 \pm 0.01$ & $6.34 \pm 0.01$ & $6.21 \pm 0.11$ & $6.04 \pm 0.03$ & $5.44 \pm 0.05$ & 20.12 \\
& $30 \%$ & $6.79 \pm 0.02$ & $6.59 \pm 0.02$ & $6.11 \pm 0.04$ & $5.97 \pm 0.08$ & $5.23 \pm 0.10$ & 22.97 \\
& $40 \%$ & $6.90 \pm 0.03$ & $6.71 \pm 0.03$ & $6.09 \pm 0.14$ & $5.99 \pm 0.12$ & $5.33 \pm 0.15$ & 22.75 \\
\hline
\end{tabular}

Each value represents mean \pm standard error of 3 replicates. WEO: Waste engine oil; MSM: mineral salt medium

Table 4: EC values of MSM amended with varying concentrations of waste engine oil Inoculated with selected bacterial isolates

\begin{tabular}{llllllll}
\multicolumn{2}{c}{ Table 4: EC values of MSM amended with varying concentrations of waste engine oil lnoculated with selected bacterial isolates } \\
\hline Bacterial isolates & WEO & Day 0 & Day 10 & Day 20 & Day 30 & Day 40 & $\begin{array}{l}\text { Percentage } \\
\text { Increase }\end{array}$ \\
\hline Conc. & & & & & & & \\
& $10 \%$ & $176.29 \pm 0.01$ & $269.22 \pm 0.01$ & $355.36 \pm 0.01$ & $467.88 \pm 0.01$ & $619.19 \pm 0.22$ & 71.53 \\
& $20 \%$ & $196.10 \pm 0.14$ & $283.39 \pm 0.23$ & $374.07 \pm 0.20$ & $176.72 \pm 0.13$ & $651.78 \pm 0.13$ & 69.91 \\
Corynebacterium sp. & $10 \%$ & $204.59 \pm 0.21$ & $294.08 \pm 0.21$ & $388.19 \pm 0.18$ & $483.39 \pm 0.32$ & $676.37 \pm 0.11$ & 69.75 \\
& $20 \%$ & $215.35 \pm 0.33$ & $309.56 \pm 0.15$ & $408.62 \pm 0.12$ & $193.04 \pm 0.19$ & $711.97 \pm 0.14$ & 69.75 \\
& $40 \%$ & $206.42 \pm 0.20$ & $298.30 \pm 0.11$ & $393.76 \pm 0.01$ & $519.76 \pm 0.05$ & $696.08 \pm 0.42$ & 70.45 \\
Bacillus sp. & $30 \%$ & $226.69 \pm 0.01$ & $325.85 \pm 0.11$ & $430.12 \pm 0.41$ & $567.76 \pm 0.15$ & $729.44 \pm 0.15$ & 68.93 \\
& $40 \%$ & $238.62 \pm 0.21$ & $343.00 \pm 0.14$ & $452.76 \pm 0.04$ & $597.64 \pm 0.32$ & $778.89 \pm 0.02$ & 69.63 \\
& $10 \%$ & $186.29 \pm 0.11$ & $292.10 \pm 0.21$ & $386.10 \pm 0.01$ & $411.05 \pm 0.02$ & $721.19 \pm 0.15$ & 74.17 \\
Control & $20 \%$ & $196.10 \pm 0.23$ & $283.39 \pm 0.01$ & $374.07 \pm 0.03$ & $176.72 \pm 0.21$ & $651.78 \pm 0.01$ & 69.93 \\
& $30 \%$ & $206.42 \pm 0.17$ & $298.30 \pm 0.12$ & $393.76 \pm 0.02$ & $519.76 \pm 0.11$ & $696.08 \pm 0.01$ & 70.34 \\
& $40 \%$ & $217.28 \pm 0.12$ & $314.00 \pm 0.02$ & $414.48 \pm 0.21$ & $547.11 \pm 0.31$ & $722.19 \pm 0.19$ & 69.91 \\
& $10 \%$ & $180.21 \pm 0.01$ & $191.29 \pm 0.11$ & $201.21 \pm 0.02$ & $215.25 \pm 0.01$ & $235.01 \pm 0.02$ & 23.32 \\
& $20 \%$ & $191.10 \pm 0.02$ & $200.01 \pm 0.10$ & $209.11 \pm 0.12$ & $223.31 \pm 0.23$ & $240.40 \pm 0.30$ & 20.51 \\
& $30 \%$ & $199.12 \pm 0.10$ & $211.02 \pm 0.14$ & $220.16 \pm 0.41$ & $235.11 \pm 0.20$ & $252.19 \pm 0.18$ & 21.04 \\
& $40 \%$ & $197.21 \pm 0.11$ & $209.02 \pm 0.22$ & $215.23 \pm 0.21$ & $235.04 \pm 0.14$ & $252.31 \pm 0.01$ & 21.84 \\
\hline
\end{tabular}

Each value represents mean \pm standard error of 3 replicates. WEO: Waste engine oil; MSM: mineral salt medium

The results presented in Table 1 indicated that the waste engine oil contaminated soils contained more nutrients than the control, hence, high numbers of certain oil degrading microorganisms were recorded in oil polluted soil which point to the obvious that these bacterial isolates are vigorous degraders of the pollutant in the soil environment as documented earlier by Okerentugba and Ezeronye (2003). Also, this report is corroborated by Jesubunmi, (2014) where higher number of oil degrading microorganisms were present in spent engine oil contaminated soils. The isolation of these bacterial isolates were not surprising 
as they are soil borne microorganisms which are known to grow, multiply and increase in cell number during the degradation processes, thus, demonstrating their abilities to utilize waste engine oil as their sole source of carbon and energy. The bacteria reported in this study have been documented by earlier researchers on oil polluted soils though there were some variations (Khan and Rizvi, 2011; Abioye et al., 2012; Shittu and Ogor, 2018). Khan and Rizvi (2011) and Abioye et al. (2012) isolated Pseudomonas, Bacillus, Micrococcus and other bacterial isolates from engine oil contaminated soil. Also, Ogunbayo et al. (2012) as well as Shittu and Ogor, (2018) isolated Pseudomonas, Bacillus and Rhodococcus species, in addition to other bacterial isolates from waste engine oil contaminated soil. These variations could be attributed to differences in culture medium used for growth as well as other environmental factors.

Table 5: THC values of MSM amended with varying concentrations of waste engine oil inoculated with Pseudomonas, Corynebacterium

\begin{tabular}{llllllll} 
& & & & & \multicolumn{2}{c}{ and Bacillus specie } \\
\hline Bacterial isolates & WEO & Day 0 & Day 10 & Day 20 & Day 30 & Day 40 & $\begin{array}{l}\text { Percentage } \\
\text { Reduction }\end{array}$ \\
\hline Conc. & & & & & & 93.10 \\
& $10 \%$ & $204.37 \pm 0.10$ & $108.31 \pm 0.22$ & $38.99 \pm 0.12$ & $20.67 \pm 0.11$ & $14.11 \pm 0.25$ & 93.10 \\
& $20 \%$ & $268.90 \pm 0.12$ & $142.52 \pm 0.10$ & $51.31 \pm 0.44$ & $27.19 \pm 0.10$ & $18.56 \pm 0.11$ & 9.10 \\
& $30 \%$ & $455.77 \pm 0.41$ & $241.56 \pm 0.05$ & $86.96 \pm 0.11$ & $46.09 \pm 0.04$ & $24.43 \pm 0.42$ & 94.64 \\
Corynebacterium sp. & $40 \%$ & $599.69 \pm 0.21$ & $317.84 \pm 0.24$ & $114.42 \pm 0.21$ & $60.64 \pm 0.14$ & $32.14 \pm 0.17$ & 94.64 \\
& $10 \%$ & $224.44 \pm 0.33$ & $103.24 \pm 0.19$ & $37.17 \pm 0.32$ & $17.10 \pm 0.23$ & $10.13 \pm 0.10$ & 95.49 \\
& $20 \%$ & $295.31 \pm 0.16$ & $135.84 \pm 0.01$ & $48.90 \pm 0.67$ & $22.50 \pm 0.65$ & $13.33 \pm 0.21$ & 95.48 \\
Bacillus sp. & $30 \%$ & $500.53 \pm 0.04$ & $230.24 \pm 0.11$ & $82.89 \pm 0.15$ & $38.13 \pm 0.61$ & $17.54 \pm 0.44$ & 96.50 \\
& $40 \%$ & $658.59 \pm 0.01$ & $302.95 \pm 0.03$ & $109.06 \pm 0.23$ & $50.17 \pm 0.82$ & $23.08 \pm 0.63$ & 96.50 \\
& $10 \%$ & $186.29 \pm 0.41$ & $101.10 \pm 0.02$ & $96.36 \pm 0.03$ & $47.88 \pm 0.18$ & $29.19 \pm 0.13$ & 84.33 \\
Control & $20 \%$ & $196.10 \pm 0.11$ & $145.39 \pm 0.11$ & $103.07 \pm 0.43$ & $76.72 \pm 0.10$ & $21.78 \pm 0.37$ & 88.89 \\
& $30 \%$ & $206.42 \pm 0.10$ & $186.30 \pm 0.20$ & $111.76 \pm 0.62$ & $59.76 \pm 0.01$ & $26.08 \pm 0.11$ & 87.37 \\
& $40 \%$ & $217.28 \pm 0.21$ & $114.00 \pm 0.17$ & $96.48 \pm 0.11$ & $57.11 \pm 0.23$ & $19.19 \pm 0.23$ & 91.17 \\
& $10 \%$ & $206.14 \pm 0.13$ & $200.22 \pm 0.18$ & $192.05 \pm 0.01$ & $180.11 \pm 0.23$ & $162.25 \pm 0.21$ & 21.29 \\
& $20 \%$ & $312.05 \pm 0.11$ & $304.15 \pm 0.10$ & $297.15 \pm 0.22$ & $279.10 \pm 0.02$ & $258.04 \pm 0.32$ & 17.31 \\
& $30 \%$ & $481.25 \pm 0.02$ & $462.25 \pm 0.21$ & $449.25 \pm 0.41$ & $432.15 \pm 0.24$ & $397.41 \pm 0.12$ & 17.42 \\
& $40 \%$ & $531.51 \pm 0.08$ & $511.14 \pm 0.04$ & $499.02 \pm 0.04$ & $470.16 \pm 0.11$ & $435.16 \pm 0.31$ & 18.13 \\
\hline
\end{tabular}

Each value represents mean \pm standard error of 3 replicates. WEO: Waste engine oil; MSM: mineral salt medium

Three parameters; $\mathrm{pH}$, electrical, conductivity and total hydrocarbon content were used to monitor biodegradation potentials of Corynebacterium, Pseudomonas and Bacillus species. The results revealed from this study showed that both $\mathrm{pH}$ and THC values reduced with increasing period of incubation. This indicated that biodegradation activity was in process. The decrease recorded in the $\mathrm{pH}$ values was responsible for the increasing in acidity, which results from the breakdown of waste engine oil into carbon (iv) oxide and water. These subsequently combine to form carbonic acid (Shittu and Ogor, 2018). The increase in incubation period could have also accounted for the reduction in the total hydrocarbon content of the medium. This means that the hydrocarbons were utilized by these bacterial isolates during the biodegradation process as a source of carbon and energy (Cvengros et al., 2017).

However, the electrical conductivity values were on the increase unlike the $\mathrm{pH}$ and total hydrocarbon content which were decreasing for all the bacterial isolates used in the biodegradation studies. The increase in electrical conductivity values could be due to the release of cations and anions which resulted from the breakdown of hydrocarbons. However, these cations and anions are known to conduct electric current (Enerijiofi and Ekhaise, 2019). The increase in electrical conductivity values with increasing days of incubation implies that the process of degrading the waste engine oil by the bacterial isolates was effective.

This result is supported by Umanu et al. (2013) and Amal and Saad (2018) where they posited that biodegradation of waste engine oil during a given number of days under the same environmental conditions is affiliated with the nature of the species within the culture that can use up a percentage of the compound. The study revealed that the bacterial isolates selected possessed the ability at different rates to utilize hydrocarbon as substrate which corroborates with earlier submission of Ekanem and Ogunjobi (2017) on hydrocarbon degradation potentials of bacteria isolated from spent lubricating oil contaminated soils. However, Corynebacterium sp. gave the best degradation ability compared to Bacillus and Pseudomonas species.

Conclusion: This study revealed that Pseudomonas, Corynebacterium and Bacillus species could be used for the bioremediation of waste engine oil as recorded in the three parameters; $\mathrm{pH}$, electrical conductivity and total hydrocarbon content monitored. However, Corynebacterium sp. was the most effective bacterial isolate in the reduction of total hydrocarbon content. 


\section{REFERENCES}

Abioye, OP; Agamuthu, P; Aziz, AR (2012). Biodegradation of used motor oil in soil using Organic Waste Amendments. Biotechnol. Res. Inter. 2: 1-8.

Adeline, SYT; Carol, HCT; and Aw, CS (2009). Hydrocarbon degradation by isolate Pseudomonas lundensis UTAR FBE2. Malaysian J. Microbiol. 5 (2): $104-108$

Ajuzie, CU; Atuanya, EI; Enerijiofi, KE (2015). Biodegradation potentials of microorganisms isolated from Eleme petrochemical industrial effluent NISEB $J$. 15 (15): $128-136$

Amal, AA; Saad, HK (2018). Biological treatment of used engine oil by single and mixed bacterial cultures isolated from soil of mechanic workshops. $J$. Biotechnology Res. Centre. 12 (1): 115 - 123.

Azubuike, CC; Chikere, CB; Okpokwasilli, GC (2016). Bioremediation techniques- classification based on site of application: principles, advantages, limitations and prospects World Journal of Microbiology and Biotechnology. 32(1): 180.

Balachandran, C; Duraipan diyan, V; Balakrishna, K; Ignacimuthu, S (2012). Petroleum and polycyclic aromatic hydcarbons (PAHs) degradation and naphthalene metabolismin in Streptomyces sp. (ERICPDA-1) isolated from oil contaminated soil. Bioresource Technology. 112: 86-90.

Bharathi, B., Gayathiri, E., Natarajan, S., Selvadhas, S. and Kakaikandham, R. (2017). Biodegradation of crude oil by bacteria isolated from crude oil contaminated soil a review. International Journal of Development and Research. 7 (12): $17392-17397$

Chen, QG; Bao, MT; Fan, XN; Liang, SK; Sun, PY (2013). Rhamnolipids enhance marine oil spill bioremediation in laboratory system. Marine Pollution Bulletin. 71(12):69-75.

Cvengros, J; Liptaj, T; Pronayova, N (2017). Study of polyaromatic hydrocarbons in current used motor oils. Inter. J. Petrochem. Sci. Engineering. 2 (7): 1-9.

Ekanem, JO; Ogunjobi, AA (2017). Hydrocarbon degradation potentials of bacteria isolated from spent lubricating oil contaminated soils. J. Appl. Sci. Environ. Manage. 21 (5):973-979

Enerijiofi, KE; Chukwuma, CA (2018). Optimisation control process of cyanide biodegradation from cassava mill effluent (CME) using indigenous microorganisms. Studia Universitatis Babeş-Bolyai Biologia, 63 (2): 6172

Enerijiofi, KE; Ekhaise, FO (2019). Physiochemical and microbiological qualities of Government approved solid waste dumpsites in Benin City. Dutse J. Pure. Appl. Sci. 5 (2a): 12 - 22

Jesubunmi, CO (2014). Isolation of oil degrading microorganisms in spent engine oil contaminated soil. J. Biol. Agric. Healthcare. 4 (25): 191 - 195

Khan, JA; Rizvi, SH (2011). Isolation and characterization of microorganism from oil contaminated sites. $A d v$. Appl. Sci. Res. 2(3):455-460

Marinescu, M; Dumitru, M; Lacatusu, A. (2009). Biodegradation of petroleum hydrocarbons in an artificial polluted soil. Res. J. Agric. Sci. 41 (2): 157 162

Meeboon, N; Kaewsuwan, S; Leigh, M; Maneerat, S (2016). Assessment of the bacterial community of soils contaminated with used lubricating oil by PCR-DGGE. Songklanakarin J. Sci. Technol. 38 (6):667-674.

Obayori, OS; Salam, LB; Ogunwumi, OS (2015). Biodegradation of fresh and used engine oils by Pseudomonas aeruginosa LP5. J. Biorem. Biodegrad.. 5(1): 1-7

Ogunbayo, AO; Olanipekun, OO; Layokun, SK (2012). A study of the abilities of Pseudomonas aeruginosa and Pseudomonas fluorescens to degrade diesel oil. $J$. Emerg. Trends in Engineer. Appl. Sci. 3(3): 429-434.

Okerentugba, PO; Ezeronye, OU (2003). Petroleum degrading potentials of single and mixed microbial cultures from rivers and refinery effluent in Nigeria. Afr. J. Biotechnol. 2 (9): $288-292$

Pandey, P; Pathak, H; Dave, S (2016). Microbial Ecology of hydrocarbon degradation in the soil: A Review Res. $J$. Environ. Toxicol. 10 (1): 1-15.

Shittu, HO; Ogor, VN (2018). Investigating the genetic basis of bioremediation activity of Corynebacterium and Bacillus Species. Sam. Adegboyega Uni. Sci. Technol. J. 3 (1): 28-39.

Umanu, G; Akpe, AR; Omoikhudu, AR (2013). Oil degradation assessment of bacteria isolated from used motor oil contaminated soils in Ota, Nigeria. Inter. $J$. Adv. Biol. Res. 3 (4): 506 - 513

Wang, Y; Feng, J; Lin, Q; Lyu, X; Wang, X; Wang, G (2013). Effect of crude oil contamination on soil physical and chemical properties in Momoge Weland, China Chinese Geog. Sci. 23 (6): 708 - 715 